\title{
Monitoring a Calcium Biofortification Workflow in an Orchard of Pyrus communis var. Rocha Applying Precision Agriculture Technology ${ }^{\dagger}$
}

\author{
Cláudia Campos Pessoa 1,2,*D, Diana Daccak ${ }^{1,2}$ (D) Inês Carmo Luís ${ }^{1,2}$ (D) Ana C. Marques ${ }^{1,2}$ (D), \\ Ana Rita F. Coelho 1,2 (D), João Caleiro ${ }^{1}$, Maria Manuela Silva ${ }^{2,3}{ }^{\mathbb{D}}$, José Carlos Kullberg ${ }^{1,2}$,

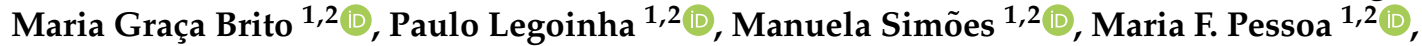 \\ Fernando H. Reboredo ${ }^{1,2}\left(\mathbb{D}\right.$, Maria José Silva ${ }^{2,4}$, José N. Semedo ${ }^{2,5}$, Isabel P. Pais ${ }^{2,5}$, Ana P. Rodrigues 4 (D, \\ Paula Scotti Campos ${ }^{2,5}$ (D) José C. Ramalho ${ }^{2,4}$ (D) and Fernando C. Lidon ${ }^{1,2}$
}

1 Earth Sciences Department, Faculdade de Ciências e Tecnologia, Campus da Caparica, Universidade Nova de Lisboa, 2829-516 Caparica, Portugal; d.daccak@campus.fct.unl.pt (D.D.); idc.rodrigues@campus.fct.unl.pt (I.C.L.); amc.marques@campus.fct.unl.pt (A.C.M.); arf.coelho@campus.fct.unl.pt (A.R.F.C.); jc.caleiro@campus.fct.unl.pt (J.C.); jck@fct.unl.pt (J.C.K.); mgb@fct.unl.pt (M.G.B.); pal@fct.unl.pt (P.L.); mmsr@fct.unl.pt (M.S.); mfgp@fct.unl.pt (M.F.P.); fhr@fct.unl.pt (F.H.R.); fjl@fct.unl.pt (F.C.L.)

2 GeoBioTec Research Center, Faculdade de Ciências e Tecnologia, Campus da Caparica, Universidade Nova de Lisboa, 2829-516 Caparica, Portugal; abreusilva.manuela@gmail.com (M.M.S.); mjsilva@isa.ulisboa.pt (M.J.S.); jose.semedo@iniav.pt (J.N.S.); isabel.pais@iniav.pt (I.P.P.); paula.scotti@iniav.pt (P.S.C.); cochichor@mail.telepac.pt (J.C.R.)

check for updates

Citation: Pessoa, C.C.; Daccak, D.; Luís, I.C.; Marques, A.C.; Coelho, A.R.F.; Caleiro, J.; Silva, M.M.; Kullberg, J.C.; Brito, M.G.; Legoinha, P.; et al. Monitoring a Calcium Biofortification Workflow in an Orchard of Pyrus communis var. Rocha Applying Precision Agriculture Technology. Biol. Life Sci. Forum 2021, 3, 3. https://doi.org/ 10.3390/IECAG2021-09661

Academic Editor: Youssef Roupha

Published: 30 April 2021

Publisher's Note: MDPI stays neutral with regard to jurisdictional claims in published maps and institutional affiliations.

Copyright: (c) 2021 by the authors. Licensee MDPI, Basel, Switzerland. This article is an open access article distributed under the terms and conditions of the Creative Commons Attribution (CC BY) license (https:/ / creativecommons.org/licenses/by/ $4.0 /)$.
3 Escola Superior de Educação Almeida Garrett (ESEAG-COFAC), Av. Campo Grande 376, 1749-024 Lisboa, Portugal

4 PlantStress \& Biodiversity Lab, Centro de Estudos Florestais (CEF), Instituto Superior Agronomia (ISA), Universidade de Lisboa, Quinta do Marquês, Av. República, 1349-017 Lisboa, Portugal; anadr@isa.ulisboa.pt

5 Instituto Nacional de Investigação Agrária e Veterinária I.P. (INIAV), Av. República, Quinta do Marquês, 2780-157 Oeiras, Portugal

* Correspondence: c.pessoa@campus.fct.unl.pt

+ Presented at the 1st International Electronic Conference on Agronomy, 3-17 May 2021; Available online: https:/ / sciforum.net/conference/IECAG2021.

Abstract: Smart farming techniques can be used to maximize food production. This can be achieved by the rapid detection of variations in crops and clever use of resources such as water and fertilizers, which might minimize crop stress through direct target practices. In an orchard located in the West region of Portugal (GPS coordinates $39^{\circ} 23^{\prime} 28.997^{\prime \prime} \mathrm{N} ; 9^{\circ} 4^{\prime} 52.483^{\prime \prime} \mathrm{W}$ ), a Ca biofortification workflow with seven foliar sprays of $\mathrm{CaCl}_{2}\left(4 \mathrm{~kg} \mathrm{ha}^{-1}\right.$ and $\left.8 \mathrm{~kg} \mathrm{ha}^{-1}\right)$ was used to increase Ca contents in "Rocha" pear trees. During the biofortification process, an Unmanned Aerial Vehicle, synchronized by GPS, was used to characterize the orchard regarding its morphology (slope) and to monitor trees (NDVI-Normalized Difference Vegetation Index). These data were correlated with Ca content (assessed by $\mathrm{X}$-ray fluorescence analysis) and photoassimilate synthesis (assessed by leaf gas exchange measurements). The orchard showed no major slopes and after four sprays with $\mathrm{CaCl}_{2}$, NDVI values revealed no major differences between the control and sprayed trees. Accordingly, leaf gas exchange parameters did not reveal negative impacts in the photoassimilate synthesis of the sprayed trees, although in the leaves Ca content significantly increased. The use of precision agriculture techniques in correlation with other analyses to assess plant stress is discussed.

Keywords: biofortification; calcium; leaf gas exchange; NDVI; pears; precision agriculture; X-ray fluorescence analysis 


\section{Introduction}

The agro-industrial sector will face challenges to feed an exponentially growing population, set to reach 9.1 billion by 2050 [1]. In addition, consumers needs must avoid the development of pathologies related to nutrition deficits, in the face of scarcity of resources [2]. Since calcium (Ca) largely performs structural functions in the human body, its deficits are related to the development of pathologies such as rickets, osteopenia or osteoporosis, which can interfere with bone formation (deformities) and structure (leading to fractures) [3].

To address this issue, the adaptation and optimization of agricultural practices are bound to happen. In this context, precision agriculture focuses on the optimization and sustainable production of crops, using both sensors and software to retrieve data (namely edaphoclimateric conditions) and acquire high-resolution images (from satellites or airborne platforms) for further processing [4]. Very recently, UAV (Unmanned Aerial Vehicle) technology has evolved to allow its use for the assessment of agricultural plots, in contrast to the NDVI (Normalized Difference Vegetation Index) techniques more commonly used, its acquisition being based in aerial images that can be an alternative to proximal (on soil) sensors [5]. The efficient use of both techniques can contribute to financial savings in productivity factors of crops and these practices can also be implemented in small farms, with the economic gains surpassing the costs of this technology's implementation [5]. On the other hand, recent studies using agronomic biofortification techniques have been performed in different cultures such as rice, wheat, grapes, potatoes and apples to increase the mineral content of $\mathrm{Se}, \mathrm{Zn}$ and $\mathrm{Ca}$, respectively, providing the opportunity to attain functional products [6-11]. Agronomic biofortification workflows with foliar sprays can thus be used to increase the content of a target mineral in the edible part of plants; however, it is also important to avoid negative impacts on the agronomic performance of plants [12,13].

Rocha pears are a typical Portuguese variety, produced mainly in the West region $(11,000$ ha) of Portugal, with an average annual total production of 173,000 tons, where at least $60 \%$ is exported [14]. This study will merge the use of precision agriculture (UAVs), in situ and laboratory analysis, to characterize and monitor an orchard of Pyrus communis L. var Rocha during a Ca biofortification workflow.

\section{Materials and Methods}

\subsection{Biofortification Itinerary}

In an orchard (coordinates $39^{\circ} 23^{\prime} 28.997^{\prime \prime} \mathrm{N} ; 9^{\circ} 4^{\prime} 52.483^{\prime \prime} \mathrm{W}$ ) allocated in the West region of Portugal, a total of seven foliar sprays, with 15 days spacing between each, were performed between 20th April and 3rd August 2019. Three rows with twelve trees each were monitored (one row was kept between sprayed rows to avoid contaminations). One was kept as the control (i.e., no Ca sprays were performed), and for the remaining two rows, $\mathrm{CaCl}_{2}\left(4 \mathrm{~kg} \mathrm{ha}^{-1}\right)$ was applied three times (thus in a total of 24 trees). Then, for the last four sprays, the concentration in one of the rows was doubled to $8 \mathrm{~kg} \mathrm{ha}^{-1}$. Fruits were harvested on 3rd of September 2019. During the experimental trial (April to September), air temperatures varied between 8 and $33^{\circ} \mathrm{C}$ and total precipitation reached $11.68 \mathrm{~mm}$.

\subsection{Orchard Characterization and NDVI}

The orchard was flown over twice with an Unmanned Aerial Vehicle (equipped with altimetric measurement sensors) synchronized by GPS, as described in other studies [9]. The first flight was performed before applying the biofortification itinerary for morphological characterization (namely slopes), while the latter meant to characterize vegetation indexes (monitor differences in vigor between the control and sprayed trees after four sprays) and further interpolation with levels of mineral content.

\subsection{Leaf Gas Exchange}

Leaf gas exchange parameters were determined using 4-6 randomized leaves per treatment, on 12th June, 26th July and 12th September, as described in other studies [15]. 
Under photosynthetic steady-state conditions after ca. $2 \mathrm{~h}$ of illumination (in the middle morning), leaf rates of net photosynthesis $\left(\mathrm{P}_{\mathrm{n}}\right)$, stomatal conductance to water vapor $\left(g_{s}\right)$ and transpiration $(E)$ were attained. Through $P_{n}$-to-E ratio, leaf instantaneous wateruse efficiency (iWUE) was calculated. The measurements were obtained with a portable open-system infrared gas analyzer (Li-Cor 6400, LiCor, Lincoln, NE, USA) under environmental conditions, with external $\mathrm{CO}_{2}$ (ca. 400 ppm) and PPFD varying between 1200 and $1400 \mu \mathrm{mol} \mathrm{m}{ }^{-2} \mathrm{~s}^{-1}$.

\subsection{Calcium Content in Leaves}

In randomized leaves, Ca contents were determined four times during the trees productive cycle (on the 21st May, 12th June, 11th and 25th of July 2019) using an XRF analyzer (model XL3t 950 He GOLDD+) under He atmosphere [7]. The leaves were cut, dried (at $60{ }^{\circ} \mathrm{C}$, until constant weight) and then ground and processed into pellets.

\subsection{Statistical Analysis}

Statistical analysis was carried out using a two-way ANOVA $(p \leq 0.05)$, to assess differences between treatments $(a, b)$ and between different moments of analyses $(r, s, t)$, and then a Tukey's for mean comparison was performed, considering a $95 \%$ confidence level.

\section{Results}

Nearly $80 \%$ of the total area of the orchard presents a low drainage surface (Figure 1), while the remaining area is classified as moderate, indicating the absence of high drainage sections. Regarding NDVI values (Table 1), the mean value of control trees was slightly higher than sprayed trees, and minimum and maximum values varied between 0.420 and 0.440 and 0.906 and 0.914 , respectively.

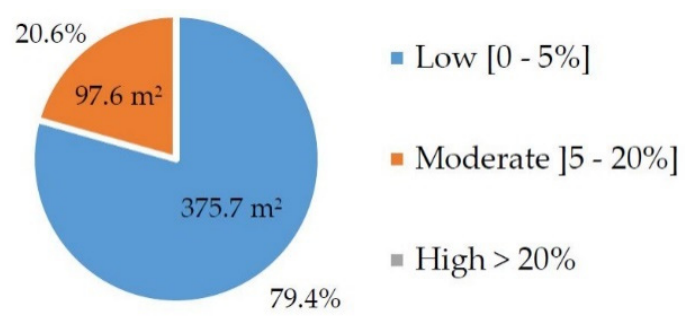

Figure 1. Slope/surface drainage characterization calculated from images of UAVs of an orchard from Pyrus communis L., variety Rocha, before leaf spray.

Table 1. Minimum, maximum and mean values of normalized vegetation index (NDVI) \pm SD calculated from images of UAVs (before foliar sprays) in trees $(n=12)$ from Pyrus communis L., variety Rocha, after the 4th (25-6-2019) leaf spraying. Ctr = Control; $4 \%$ corresponds to the exclusive pulverization of $4 \mathrm{~kg} \mathrm{ha}^{-1} ; 8 \%$ corresponds to three pulverizations of $4 \mathrm{~kg} \mathrm{ha}^{-1}$, and four pulverizations with $8 \mathrm{~kg} \mathrm{ha}^{-1}$.

\begin{tabular}{cccc}
\hline Treatments & Minimum & Maximum & Mean \pm SD \\
\hline Ctr & 0.440 & 0.914 & $0.800 \pm 0.093$ \\
\hline $4 \%$ & 0.440 & 0.906 & $0.781 \pm 0.111$ \\
\hline $8 \%$ & 0.420 & 0.914 & $0.797 \pm 0.110$ \\
\hline
\end{tabular}

Considering leaf gas exchanges (Table 2), for the last two dates of analyses, trees sprayed with $8 \%$ revealed a slight tendency for higher $P_{n}, g_{s}$ and $E$ values and minor iWUE in comparison with the control. 
Table 2. Average $(n=4)+S E$ of leaf gas exchange parameters, $P_{n}, g_{s}, E$ and iWUE in leaves of Pyrus communis L., variety Rocha pear, submitted to Ca biofortification, at 12th June, 26th July and 12th September 2019 (after the 3rd, 6th and 7th sprays, respectively). Letters a, b, c indicate significant differences between the treatments, and r, s, t between different moments of analyses (statistical analysis using the single-factor ANOVA test, $p \leq 0.05$ ). Ctr $=$ Control; $4 \%$ corresponds to the exclusive pulverization of $4 \mathrm{~kg} \mathrm{ha}^{-1} ; 8 \%$ corresponds to three pulverizations of $4 \mathrm{~kg} \mathrm{ha}^{-1}$, and four pulverizations with $8 \mathrm{~kg} \mathrm{ha}^{-1}$.

\begin{tabular}{|c|c|c|c|}
\hline Treatments & 12th June & 26th July & 12th September \\
\hline \multicolumn{4}{|c|}{$P_{n}\left(\mu \mathrm{mol} \mathrm{CO} \mathrm{m}^{-2} s^{-1}\right)$} \\
\hline Ctr & $17.69 \pm 0.24 a, r$ & $16.09 \pm 0.55$ as & $7.77 \pm 0.25$ at \\
\hline $4 \%$ & $17.70 \pm 0.13 \mathrm{a}, \mathrm{r}$ & $15.49 \pm 0.23$ as & $7.47 \pm 0.39$ at \\
\hline $8 \%$ & $17.85 \pm 0.19 \mathrm{a}, \mathrm{r}$ & $16.49 \pm 0.32 \mathrm{as}$ & $8.37 \pm 0.33$ at \\
\hline \multicolumn{4}{|c|}{$\mathrm{g}_{\mathrm{s}}\left(\mathrm{mmol} \mathrm{H}_{2} \mathrm{O} \mathrm{m}^{-2} \mathrm{~s}^{-1}\right)$} \\
\hline $0 \%$ & $255.6 \pm 6.8 \mathrm{ar}$ & $199.0 \pm 10.9 \mathrm{bs}$ & $68.5 \pm 3.8$ at \\
\hline $4 \%$ & $252.4 \pm 5.1 \mathrm{ar}$ & $221.1 \pm 4.9 \mathrm{bs}$ & $65.5 \pm 5.1$ at \\
\hline $8 \%$ & $245.2 \pm 3.9 \mathrm{ar}$ & $269.0 \pm 8.8 \mathrm{ar}$ & $76.6 \pm 5.5$ as \\
\hline \multicolumn{4}{|c|}{$\mathrm{E}\left(\mathrm{mmol} \mathrm{H} \mathrm{H}_{2} \mathrm{O} \mathrm{m}^{-2} \mathrm{~s}^{-1}\right)$} \\
\hline $0 \%$ & $3.27 \pm 0.06 \mathrm{ar}$ & $2.21 \pm 0.07 \mathrm{bs}$ & $2.03 \pm 0.09 \mathrm{bs}$ \\
\hline $4 \%$ & $3.38 \pm 0.04 a r$ & $2.40 \pm 0.05 \mathrm{bs}$ & $2.17 \pm 0.13 \mathrm{bs}$ \\
\hline $8 \%$ & $3.24 \pm 0.03 \mathrm{ar}$ & $3.29 \pm 0.09 \mathrm{ar}$ & $2.53 \pm 0.15$ as \\
\hline \multicolumn{4}{|c|}{ iWUE $\left(\mathbf{m m o l ~ C O} \mathbf{~ m o l}^{-1} \mathbf{H}_{2} \mathrm{O}\right)$} \\
\hline $0 \%$ & $5.43 \pm 0.06 \mathrm{as}$ & $7.29 \pm 0.17 \mathrm{ar}$ & $3.95 \pm 0.15 a t$ \\
\hline $4 \%$ & $5.26 \pm 0.05 \mathrm{as}$ & $6.53 \pm 0.17 \mathrm{br}$ & $3.51 \pm 0.07 \mathrm{abt}$ \\
\hline $8 \%$ & $5.51 \pm 0.06 \mathrm{ar}$ & $5.08 \pm 0.12 \mathrm{cr}$ & $3.41 \pm 0.09 \mathrm{bs}$ \\
\hline
\end{tabular}

Regarding Ca contents in the leaves (Figure 2), for the same analytical experimental period, the control was significantly lower than the treatment $8 \%$ from the third spray, and from treatment $4 \%$ from the fifth foliar spray onwards. For all treatments, the last two analytical dates (after fifth and sixth foliar sprays), revealed values significantly higher than the second and the first moment of analyses (after third and second foliar sprays, respectively).
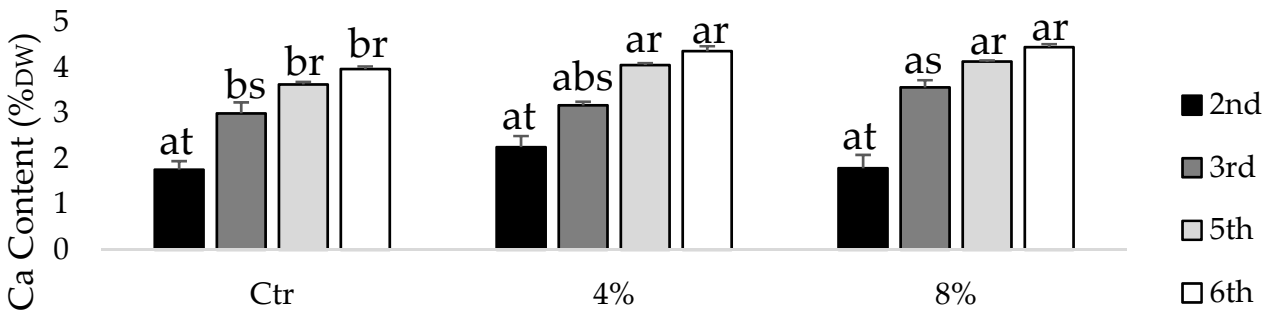

Treatments

Figure 2. Mean values of Ca contents $\pm \mathrm{SE}(\mathrm{n}=3)$ in leaves from Pyrus communis L., variety Rocha, after the 2nd (21-5-2019), 3rd (12-6-2019), 5th and 6th leaf spray (at 11-7-2019 and 25-7-2019, respectively). Letters $\mathrm{a}, \mathrm{b}$ indicate significant differences between the treatments, and $\mathrm{r}, \mathrm{s}, \mathrm{t}$ between different moments of analyses (statistical analysis using the single-factor ANOVA test, $p \leq 0.05$ ). Ctr $=$ Control; $4 \%$ corresponds to the exclusive pulverization of $4 \mathrm{~kg} \mathrm{ha}^{-1} ; 8 \%$ corresponds to three pulverizations of $4 \mathrm{~kg} \mathrm{ha}^{-1}$, and four pulverizations with $8 \mathrm{~kg} \mathrm{ha}^{-1}$. 


\section{Discussion}

Water is vital for plants' nutrient uptake, and the morphologic aspect of agricultural fields can consequently have a high impact on crop health, since slopes influence water drainage and infiltration [9]. The correct functioning of photosynthetic mechanisms also depends on water for photoassimilate production and translocation [16].

In regard to our study, the orchard mostly presents a smooth slope morphology, indicating an even accumulation of water (and subsequent infiltration into the ground) for all sprayed trees. Artificial irrigation was also performed in the orchard; thus, water was not a conditional factor for nutrient absorption from soils. Leaf gas exchange parameters also supported this conclusion, with minor decreases in $P_{n}$ and $g_{s}$ for the later period of analysis, probably related to the end of the production cycle of Rocha pear trees, with the harvest phase typically beginning from late August to September [14].

This study also showed an increase in Ca content in leaves after foliar sprays, and the slightly higher values of treatment $8 \%$ relates to the increase in $\mathrm{CaCl}_{2}$ concentration to double after the third spray. Furthermore, from the perspective of fruit biofortification, an increase in $\mathrm{Ca}$ in fruits from this variety, using the same workflow, has been reported [17]. Ca content can be linked to photosynthesis since its deficits mainly affect new leaf growth and photoassimilate production and mobilization [18]. Leaf gas exchanges and NDVI indexes support the absence of toxicity signs throughout the workflow, with sprayed trees revealing similar values to the control. NDVI values can vary between 1 and -1 , and thus, higher values indicate healthy vegetation [4]. Since all trees presented values higher than 0.75 , at this point of the workflow, no signs of disrupted vegetation were detected [5]. Additionally, the results are in accordance with this mineral's role in the preservation of photosynthetic capacity and high stomatal opening [19] linked to the stabilization of chlorophyll complexes and the maintenance of the high photochemical efficiency of PSII [18].

\section{Conclusions}

Foliar applications of $\mathrm{CaCl}_{2}$ in concentrations of 4 and $8 \mathrm{~kg} \mathrm{ha}^{-1}$ increased Ca contents in leaves of Pyrus communis L., variety Rocha. However, the vigor and respective photosynthesis mechanism of sprayed trees were not affected by the applied workflow. These interactive factors can also be due to the terrain morphology, which promotes identical water supply to plants. In this context, the use of precision agriculture techniques (namely UAVs), was successfully used with other analyses, not only to characterize the terrain, but also to monitor plants during their productive cycle.

Supplementary Materials: The following are available online at https:/ /www.mdpi.com/article/10 .3390/IECAG2021-09661/s1.

Author Contributions: Conceptualization, P.S.C., J.C.R. and F.C.L.; methodology, J.C.K., M.G.B., J.C.R. and F.C.L.; software, M.G.B. and M.J.S.; formal analysis, C.C.P., I.C.L., A.C.M., D.D., A.R.F.C., J.C., J.C.K., J.N.S., A.P.R. and J.C.R.; resources, M.M.S., J.C.K., M.G.B., P.L., M.S., M.F.P., F.H.R., I.P.P., J.C.R. and F.C.L.; writing—original draft preparation, C.C.P.; writing—review and editing, C.C.P. and F.C.L.; supervision, F.C.L.; project administration, F.C.L.; funding acquisition, F.C.L. All authors have read and agreed to the published version of the manuscript.

Funding: This research was funded by PDR2020, grant number 101-030734.

Acknowledgments: The authors thank José Henriques (HBio Lda.) for technical assistance. We also give thanks to the research centers (GeoBioTec) UIDB/04035/2020 and (CEF) UIDB/00239/2020 for support facilities. Funding from Fundação para a Ciência e Tecnologia (FCT) UIBD/150718/2020 is also greatly acknowledged.

Conflicts of Interest: The authors declare no conflict of interest. The founding sponsors had no role in the design of the study; in the collection, analyses, or interpretation of data; in the writing of the manuscript, and in the decision to publish the results. 


\section{References}

1. FAO_Food and Agriculture Organization of the United Nations. Available online: http://www.fao.org/fileadmin/templates/ wsfs/docs / expert_paper/How_to_Feed_the_World_in_2050.pdf (accessed on 2 January 2021).

2. FAO_Food and Agriculture Organization of the United Nations. The Future of Food and Agriculture-Trends and Challenges; FAO: Rome, Italy, 2017; pp. 3-16. ISBN 978-92-5-109551-5.

3. EFSA Panel on NDA. Scientific opinion on dietary reference values for calcium. EFSA J. 2015, 13, 1-82. [CrossRef]

4. Shafi, U.; Mumtaz, R.; García-Nieto, J.; Hassan, S.A.; Zaidi, S.A.; Iqbal, N. Precision Agriculture Techniques and Practices: From Considerations to Applications. Sensors 2019, 19, 3796. [CrossRef] [PubMed]

5. Loures, L.; Chamizo, A.; Ferreira, P.; Loures, A.; Castanho, R.; Panagopoulos, T. Assessing the Effectiveness of Precision Agriculture Management Systems in Mediterranean Small Farms. Sustainability 2020, 12, 3765. [CrossRef]

6. Marques, A.C.; Lidon, F.C.; Coelho, A.R.F.; Pessoa, C.C.; Luís, I.C.; Scotti-Campos, P.; Simões, M.; Almeida, A.S.; Legoinha, P.; Pessoa, M.F.; et al. Quantification and Tissue Localization of Selenium in Rice (Oryza sativa L., Poaceae) Grains: A Perspective of Agronomic Biofortification. Plants 2020, 9, 1670. [CrossRef] [PubMed]

7. Luís, I.C.; Lidon, F.C.; Pessoa, C.C.; Marques, A.C.; Coelho, A.R.F.; Simões, M.; Patanita, M.; Dôres, J.; Ramalho, J.C.; Silva, M.M.; et al. Zinc Enrichment in Two Contrasting Genotypes of Triticum aestivum L Grains: Interactions between Edaphic Conditions and Foliar Fertilizers. Plants 2021, 10, 204. [CrossRef] [PubMed]

8. Daccak, D.; Pessoa, C.C.; Coelho, A.; Marques, A.; Luís, I.; Silva, M.M.; Guerra, M.; Leitão, R.; Ramalho, J.; Simões, M.; et al. Grapes Enrichment with Zinc for Vinification: Mineral Analysis with Atomic Absorption Spectrophotometry, XRF and Tissue Analysis. In Proceedings of the 1st International Electronic Conference on Plant Science; MDPI: Basel, Switzerland, 2020. [CrossRef]

9. Coelho, A.R.F.; Lidon, F.C.; Pessoa, C.C.; Marques, A.C.; Luís, I.C.; Caleiro, J.C.; Simões, M.; Kullberg, J.; Legoinha, P.; Brito, G.; et al. Can Foliar Pulverization with $\mathrm{CaCl}_{2}$ and $\mathrm{Ca}\left(\mathrm{NO}_{3}\right)_{2}$ Trigger Ca Enrichment in Solanum Tuberosum L. Tubers? Plants 2021, 10, 245. [CrossRef] [PubMed]

10. Reboredo, F.; Sánchez, C.; Santos, M.; Ramos, P.; Rodrigues, C.; Ribeiro, V.; Pessoa, M.; Lidon, F. Calcium biofortification of apples: Implications on fruit quality parameters. In COST Action Project FA 0905 Mineral-Improved Crop Production for Healthy Food and Feed, Final Conference Agronomic, Molecular Genetics and Human Nutrition Approaches for Improving the Nutritional Quality and Safety of Food Crops; Ela Quality Resort: Antalya-Belek, Turkey, 2014; pp. 52-53.

11. Lidon, F.; Ribeiro, V.; Reboredo, F.; Pessoa, M.; Santos, M.; Ramos, P.; Sánchez, C. Calcium biofortification of apples: Interaction with Macronutrients. In COST Action Project FA 0905 Mineral-Improved Crop Production for Healthy Food and Feed, Final Conference Agronomic, Molecular Genetics and Human Nutrition Approaches for Improving the Nutritional Quality and Safety of Food Crops; Ela Quality Resort: Antalya-Belek, Turkey, 2014; pp. 102-103.

12. Singh, U.; Praharaj, C.; Chaturvedi, S.; Bohra, A. Biofortification: Introduction, approaches, limitations, and challenges. In Biofortification of Food Crops; Singh, U., Praharaj, C., Singh, S., Singh, N., Eds.; Springer: New Delhi, India; Heidelberg, Germany; New York, NY, USA; Dordrecht, The Netherlands; London, UK, 2016; pp. 3-18. [CrossRef]

13. D'Imperio, M.; Renna, M.; Cardinali, A.; Buttaro, D.; Serio, F.; Santamaria, P. Calcium biofortification and bioaccessibility in soilless “baby leaf" vegetable production. Food Chem. 2016, 213, 149-156. [CrossRef] [PubMed]

14. ANP-Associação Nacional de Produtores de Pera Rocha. Available online: https:/ / perarocha.pt/anp/ (accessed on 9 January 2021).

15. Marques, A.C.; Lidon, F.C.; Coelho, A.R.F.; Pessoa, C.C.; Luís, I.C.; Campos, P.S.; Simões, M.; Almeida, A.S.; Pessoa, M.F.; Galhano, G.; et al. Effect of Rice Grain (Oryza sativa L.) Enrichment with Selenium on Foliar Leaf Gas Exchanges and Accumulation of Nutrients. Plants 2021, 10, 288. [CrossRef] [PubMed]

16. Taiz, L.; Zeiger, E. Plant Physiology, 3rd ed.; Sinauer Associates: Sunderland, MA, USA, 2002; pp. 33-65.

17. Pessoa, C.C.; Coelho, A.; Marques, A.; Luís, I.; Daccak, D.; Silva, M.M.; Ramalho, J.; Simões, M.; Reboredo, F.; Pessoa, M.; et al. Increase of Calcium in 'Rocha' Pear (Pyrus communis L.) for Development of Functional Foods. In Proceedings of the 1st International Electronic Conference on Plant Science; MDPI: Basel, Switzerland, 2020. [CrossRef]

18. Ramalho, J.C.; Rebelo, M.C.; Santos, M.E.; Antunes, M.L.; Antonieta, M. Effects of calcium deficiency on Coffea arabica. Nutrient changes and correlation of calcium levels with some photosynthetic parameters. Plant Soil 1995, 172, 87-96. [CrossRef]

19. Ramalho, J.D.C.; Nunes, M.A. Photosynthesis impairment in Coffea arabica due to calcium deficiency. Agron. Lusit. 1999, 47, 101-116. 